\title{
Sulfosulfuron effects on growth and photosynthesis of 15 range grasses
}

\author{
THOMAS A. MONACO AND J. EARL CREECH
}

Authors are Ecologist, USDA-ARS Forage and Range Research Lab., Utah State Univ., Logan, Ut. 84322-6300 and Graduate Research Assistant, Plants, Soils, and Biometeorology Dept., Utah State Univ., Logan, Ut. 84322-4820.

Abstract

We conducted greenhouse experiments to compare photosynthetic and growth responses of $\mathbf{2}$ invasive annual grasses (downy brome = Bromus tectorum $\mathbf{L}$. and medusahead = Taeniatherum caput-medusae (L.) [Nevski]), 6 caespitose grasses, and 7 rhizomatous grasses to the herbicide sulfosulfuron (1-(2-ethylsulfonylimidazo[1,2-a]pyridin-3-ylsulfonyl)-3-(4,6-dimethoxypyrimidin-2-yl)urea). Our objectives were to identify general patterns of species responsiveness and test the hypothesis that sulfosulfuron induced reduction in photosynthetic activity and shoot growth would be more pronounced in small relative to larger plants. Small plants in a spring experiment and large plants in a summer experiment were treated with sulfosulfuron ( $\left.70 \mathrm{~g} \mathrm{ai} \mathrm{ha}^{-1}\right)$. Wildryes and bromes were consistently injured; whereas, 5 of the 7 wheatgrasses were not susceptible to sulfosulfuron. Rhizomatous grasses generally experienced greater damage from sulfosulfuron than caespitose grasses. These results suggest that sulfosulfuron would provide a useful rangeland management tool to control unwanted invasive annual grasses without significantly hindering growth and physiology of desirable rangeland grasses.

Key Words: caespitose grass, rhizomatous grass, invasive annual grass, carbon assimilation, photosystem II fluorescence, sulfonylurea herbicide

Invasive and undesirable grasses pose a tremendous threat to the productivity and ecological stability of semiarid rangelands and pastures in the western U.S. (D'Antonio and Vitousek 1992). Few managerial options exist to selectively control undesirable grasses without negatively impacting desirable perennial grasses. Sulfosulfuron (1-(2-ethylsulfonylimidazo[1,2-a]pyridin-3-ylsulfonyl)-3-(4,6-dimethoxypyrimidin-2-yl)urea) is a sulfonylurea herbicide that has been shown to selectively control the winter annuals downy brome (Bromus tectorum L.) (Geier et al. 1998, Olsen et al. 2000) and cheat (Bromus secalinus L.) (Kelley and Peeper 2003) and the troublesome rhizomatous pasture grasses quackgrass (Elytrigia repens L. Nevski) (Hageman et al. 1996) and johnsongrass (Sorghum halepense L. Pers.) (Anonymous 1999) without injuring non-target species. However, no published

Research was funded by USDA-ARS. Authors thank Justin Williams, Trevor Warburton, and Brandon Gordon for assistance in establishing plants and measuring photosynthetic parameters. We thank Drs. P. Geier, J. Evans, and S. Dewey for insightful comments on earlier drafts of this manuscript.

*Corresponding author and offprint requests: email: tmonaco@cc.usu.edu

Manuscript accepted 28 Feb. 04

\section{Resumen}

Condujimos experimentos en invernadero para comparar las respuestas fotosintéticas y de crecimiento de dos zacates anuales invasores ("Downy brome" = Bromus tectorum L. y" Medusahead" = Taeniatherum caput-medusae $($ L.) $[$ Nevski]), 6 zacates cespitosos y 7 zacates rizomatosos a la aplicación del herbicida sulfosulfuron (1-(2-ethylsulfonylimidazo[1,2-a]pyridin-3. ylsulfonyl)-3-(4,6-dimethoxypyrimidin-2-yl)urea). Nuestros objetivos fueron identificar patrones generales de respuesta de las especies y probar la hipótesis de que el sulfosulfuron indujo una reducción de la actividad fotosintética y que el crecimiento de los tallos sería mas pronunciado en plantas pequeñas en relación a plantas grandes. Las plantas pequeñas se trataron con sulfosul. furon $\left(70 \mathrm{~g} \mathrm{ai} \mathrm{ha}^{-1}\right)$ en un experimento realizado en primavera! las grandes en uno efectuado en verano. "Wildryes" y "Bromes" fueron consistentemente dañados, mientras que 5 de los" "Wheatgrasses"no fueron susceptibles al sulfosulfuron. Los zacates rizomatosos generalmente experimentaron mas daño por el sulfosulfuron que los zacates cespitosos. Estos resultados sug. ieren que el sulfosulfuron podría ser una herramienta útil de manejo de pastizales para controlar las especies invasoras no deseadas de zacates anuales sin afectar significativamente $\mathrm{el}$ crecimiento y fisiología de los zacates deseables del pastizal.

results have evaluated whether sulfosulfuron could prove helpful in managing undesirable grasses common to semiarid rangelands and pastures. In particular, the potential impacts of sulfosulfuron on a broad range of non-target desirable perennial grasses are unknown.

As a sulfonylurea herbicide, sulfosulfuron inhibits acetolactate synthase (ALS), an enzyme involved in the synthesis of the branched-chain amino acids isoleucine, valine, and leucine in susceptible plants (Chaleff and Mauvais 1984). Susceptible species are generally incapable of metabolizing sulfonylreas through hydroxylation of the phenyl ring by cytochrome P-450 (Hinz et al. 1997). In downy brome and other weedy annual grasses, patterns of susceptibility are related to their ability to metabolize sulfosulfuron (Olsen et al 2000). Species susceptible (i.e., responsive) to sulfosulfuron show reductions in shoot biomass (Blackshaw and Hamman 1998) and overall growth (Geier and Stahlman 1996).

We conducted greenhouse experiments to evaluate photosyn thetic and growth responses following exposure to sulfosulfuron for 15 grasses common to the western U.S. These experiments were designed to evaluate whether invasive annual grasses, rhi. zomatous grasses, and caespitose (i.e., bunchgrasses) grasses 
demonstrate consistent patterns of response to sulfosulfuron as opposed to making rigorous comparisons between individual species. Photosynthetic responses were measured to provide a quantitative comparison of physiological impacts that may not be immediately apparent using visual evaluations of herbicide damage. The collective photosynthetic and growth responses were weighed to identify general patterns in species responsiveness and test the hypothesis that sulfosulfuron induced reduction in photosynthetic activity and shoot growth would be more pronounced in a spring experiment with smaller plants relative to responses in a summer experiment with larger plants.

\section{Materials and Methods}

\section{Plant materials}

Plants of 2 invasive annual grasses (downy brome and medusahead [Taeniatherum caput-medusae (L.) Nevski]), 6 perennial, caespitose grasses ('Goldar' bluebunch wheatgrass [Pseudoroegneria spicata (Pursh) Löve], 'Secar' Snake River wheatgrass [Elymus wawawaiensis J. Carlson \& Barkw.], 'CD II' crested wheatgrass [Agropyron cristatum (L.) Gaertner x A. desertorum (Fisch. ex Link) Schultes], Sand Hollow big squirreltail germplasm [Elymus multisetus (J.G. Smith) M.E. Jones], Basin wildrye [Leymus cinereus (Scribn. \& Merr.) Löve], and 'Bozoisky' Russian wildrye [Psathyrostachys juncea (Fisch.) Nevski]), and 7 rhizomatous grasses ('Rosana' western wheatgrass [Pascopyrum smithii (Rydb.) Löve], 'Critana' thickspike wheatgrass [Elymus lanceolatus (Scribn. \& Sm.) Gould], 'Greenar' intermediate wheatgrass [Thinopyrum intermedium (Host) Barkw. \& Dewey], 'NewHy' wheatgrass [Elymus hoffmannii], beardless wildrye [Leymus triticoides (Buckley) Pilger], quackgrass, and 'Manchar' smooth brome [Bromus inermis Leysser]) were established in 3liter pots filled with a mixture of coarse sand and peat moss (ratio 3:1, v/v).

All grasses were established from seed with the exception of beardless wildrye and quackgrass, which were vegetatively propagated from juvenile tillers collected from mature field-grown plants. Five seeds or tillers were planted in each pot and thinned to 3 uniformly sized plants per pot after emergence. Growth rates are known to be much higher for the invasive annual grasses than the perennial grasses (Arredondo et al. 1998). To compensate for this difference, the planting of the 2

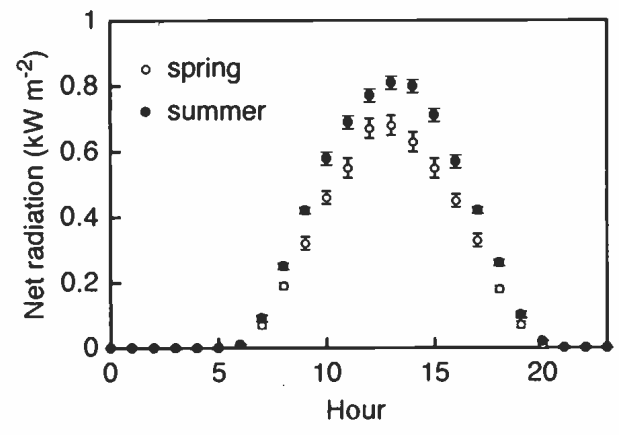

Fig. 1. Mean ( $\pm 1 S E ; n=92$ ) hourly net radia tion received on the exterior of the greenhouse during the spring and summer experiments.

annual grasses was delayed 1 month in the summer experiment so that plants would be more comparable in size and tiller number to the perennial species when the experiment was initiated.

Spring and summer experiments were conducted in a greenhouse located in Logan, Ut., U.S.A. Air temperature was maintained between 17 to $26^{\circ} \mathrm{C}$ with evaporative coolers and an application of chalk solution to the exterior of the greenhouse that reduced ambient solar radiation $(\sim 50 \%)$. Net solar radiation was measured on the exterior of greenhouse with a pyranometer (LI-200SA, Li-cor Corp., Lincoln, Neb.) during the spring and summer experiments. Mean solar radiation was consistently greater during the summer experiment between the hours of 0900 and 1800 (Fig. 1). Plants were watered daily with tap water and fertilized weekly with a complete nutrient solution (Miracle Grow All

Table 1. Mean ( $\pm 1 \mathrm{SE} ; n=8$ ) number of tillers of 2 invasive annual grasses, 6 perennial caespitose grasses, and 7 perennial rhizomatous grasses in the spring and summer experiments prior to herbicide applications. Plants in the spring experiment were smaller and had fewer tillers than plants in summer experiment.

\begin{tabular}{llcc}
\hline \hline Grass & & & \\
life form & Species & Spring Experiment & Summer Experiment \\
\hline \multirow{3}{*}{ Annual } & & $--1 .--($ Tiller number)----- \\
& downy brome & $7.3(0.8)$ & $17(1)$ \\
Caespitose & medusahead & $5.3(0.5)$ & $11(1)$ \\
& bluebunch wheatgrass & $4.9(0.6)$ & $13(3)$ \\
& Snake River wheatgrass & $8.6(0.9)$ & $25(2)$ \\
& crested wheatgrass & $7.3(0.4)$ & $23(2)$ \\
& big squirreltail & $5.3(0.4)$ & $17(2)$ \\
& basin wildrye & $2.0(0.2)$ & $6(0)$ \\
Rhizomatous & Russian wildrye & $3.9(0.1)$ & $16(2)$ \\
& western wheatgrass & $2.6(0.3)$ & $7(1)$ \\
& thickspike wheatgrass & $5.0(0.4)$ & $20(3)$ \\
& intermediate wheatgrass & $3.1(0.2)$ & $20(1)$ \\
& Newhy wheatgrass & $4.6(0.3)$ & $22(3)$ \\
& beardless wildrye & $4.4(0.3)$ & $9(1)$ \\
& quackgrass & $3.5(0.3)$ & $17(2)$ \\
& smooth brome & $2.5(0.2)$ & $30(2)$ \\
\hline
\end{tabular}

Purpose Plant Food, Scotts Miracle-Grow Products, Inc., Marysville, Ohio). Plants in the spring experiment were smaller, and had at least 1 -half the number of tillers as plants in the summer experiment, as indicated by data collected prior to initiating the experiments (Table 1).

\section{Spring Experiment}

Sulfosulfuron was applied to 4 randomly selected, individual pots of each species at a rate of $70 \mathrm{~g}_{\text {ai ha }}{ }^{-1}$ when plants had at least 2 tillers, using a custom precision table sprayer equipped with 1 flat-fan nozzle tip (TeeJet 8001E, Spraying Systems Co., Wheaton, Ill.). In addition, 4 pots of each species were designated as untreated controls. The sprayer was calibrated to deliver 179 liter $\mathrm{ha}^{-1}$ at $207 \mathrm{kPa}$. Calibration exercises were performed by placing sheets of aluminum foil on top of empty pots and passing the sprayer over the pot. Aluminum foil sheets were then immediately weighed to calculate herbicide applied per pot and fine-tune the target application rate. Sulfosulfuron was applied with a non-ionic surfactant $(0.5 \%$ v/v) (IFA S-90, Salt Lake City, Ut.). Pots containing control plants and treated plants were handled identically, but control pots were sprayed with water instead of herbicide. Hereafter, we refer to herbicide application date as Day 0. Leaf level photosynthesis and fluorescence based quantum yield of photosystem II ( $\mathrm{Fv}^{\prime} / \mathrm{Fm}$ ') were measured on Days 0,3 , 10 , and 31 between the hours of 1100 and 1300 to evaluate physiological injury and potential recovery of photosynthetic integrity of plants treated with sulfosul- 
furon. Following physiological measurements on Day 31, tiller number per plant was recorded and shoots of all plants were harvested at the soil surface and dried in a convective oven for 48 hours at $60^{\circ} \mathrm{C}$ to determine shoot dry mass.

\section{Summer Experiment}

Four pots per species were randomly assigned to either an untreated control, or sulfosulfuron at $70 \mathrm{~g}$ ai ha ${ }^{-1}$. Plants were treated when individual plants of each grass species had greater than 5 tillers per plant. Sulfosulfuron was applied with a non-ionic surfactant $(0.5 \%$ v/v) (IFA S90, Salt Lake City, Ut.) using a bicycle sprayer that delivered 171 liter ha $^{-1}$ at 250 kPA using 4 flat-fan nozzles (TeeJet 8003, Spraying Systems Co., Wheaton, Ill.). All plants were removed from the greenhouse to apply sulfosulfuron to treatment plants and water to control plants. Calibration exercises were performed by placing sheets of aluminum foil on top of empty pots and passing the sprayer over the treatment area. Aluminum sheets were then immediately weighed to calculate herbicide applied and the speed of travel of the bicycle sprayer required for the target application rate. We considered these calibration exercises to be an essential procedure because the spring and summer experiments were conducted with different herbicide application techniques.

The number of measurements associated with the summer experiment ( 90 pots x 3 plants) and our desire to avoid taking photosynthesis measurements outside of the 1000 to 1400 hour period required measuring plants using a random sampling order over a 4-day period. Thus, photosynthesis was measured for the 15 grasses between Days 7 and 10. When photosynthesis measurements were completed for all species, tiller number per plant was recorded and shoots of all plants were harvested at the soil surface and dried in a convective oven for 48 hours at $60^{\circ} \mathrm{C}$ to determine shoot dry mass.

\section{Photosynthetic and shoot growth measurements}

Leaf photosynthesis $\left(\mathrm{CO}_{2}\right.$ assimilation rate) and Fv'/Fm', a measure of the potential quantum yield of photosystem II, were taken simultaneously with a portable photosynthesis system (LI-6400; Li-Cor Corp., Lincoln, Nebr., U.S.A.) equipped with a leaf chamber fluorometer (red-blue led light source) in the spring experiment. In the summer experiment, photosynthesis was the only physiological variable measured. Pots were considered the experi- mental unit and values for the 3 plants per pot were averaged. The following environmental parameters were held constant for all photosynthesis and fluorescence measurements: IRGA (infrared gas analyzer) block temperature at $25^{\circ} \mathrm{C}$, relative humidity between 15 to $20 \%$, and $\mathrm{CO}_{2}$ concentration at $400 \mathrm{mmol} \mathrm{mol}^{-1}$. Values for photosynthetically active radiation $(P A R=400-700 \mathrm{~nm})$ in the leaf chamber was produced from a red and blue LED light source. The PAR was set to match ambient conditions in the spring experiment to account for expected differences in radiation quantity associated with measuring all species during a 31-day period. In contrast, because all plants were measured within a 4-day period in the summer experiment, PAR was always set to 800 $\mu \mathrm{mol} \mathrm{m} \mathrm{sec}^{-1}$.

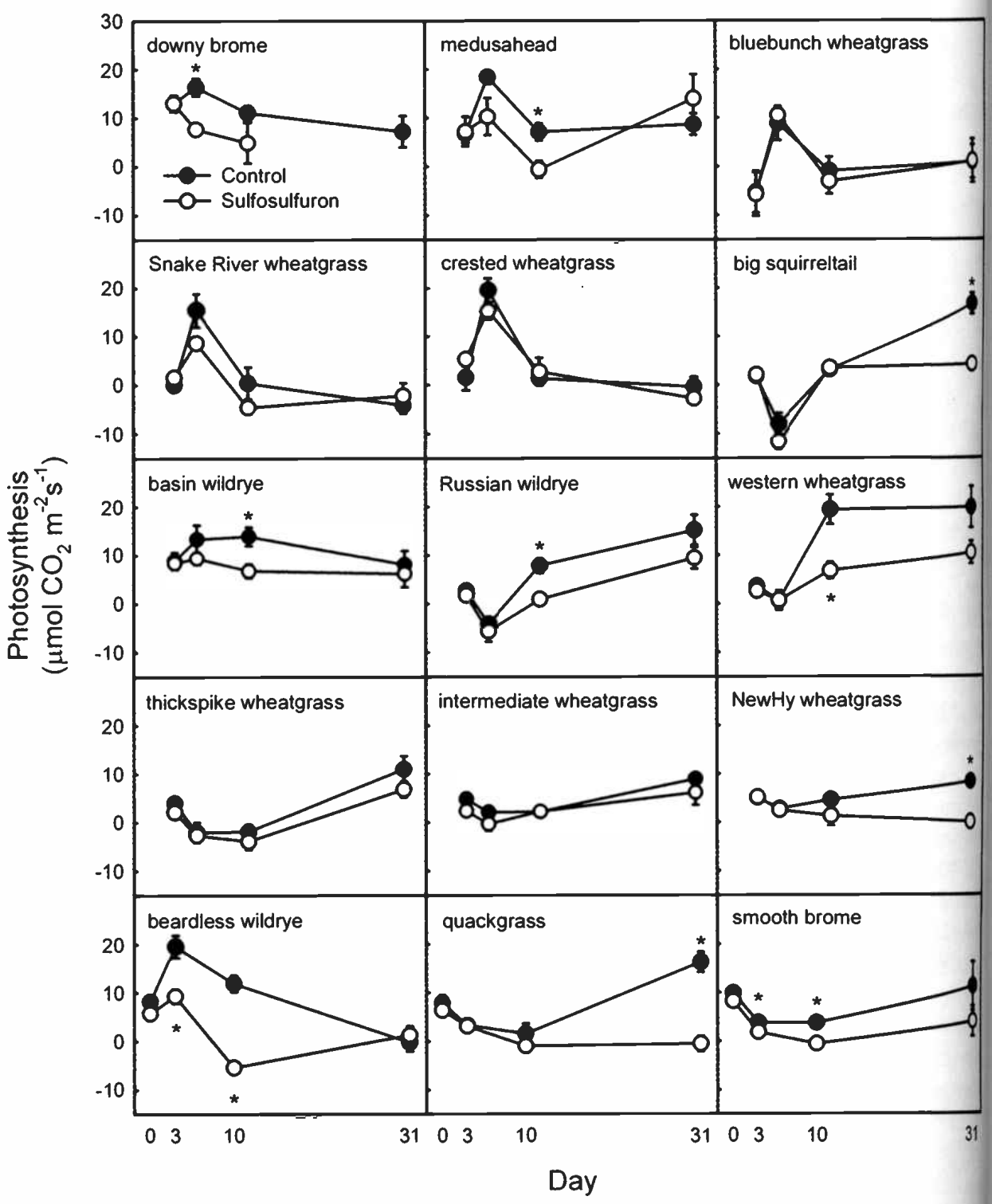

Fig. 2. Mean ( $\pm 1 \mathrm{SE}, \mathrm{n}=4$ ) leaf photosynthesis $\left(\mathrm{CO}_{2}\right.$ assimilation rate) for 15 grasses expose to sulfosulfuron at the rate of $70 \mathrm{~g}$ ai ha ${ }^{-1}$ or not treated (control). Measurements were madt prior to herbicide treatment (Day 0) and on Days 3, 10, and 31. Asterisks indicate signif. cant differences between the sulfosulfuron treatment and control within a specific day. 
Table 2. Mean $( \pm 1 \mathrm{SE} ; \mathrm{n}=4$ ) photosynthesis, number of tillers, and shoot dry mass produced by 2 invasive annual grasses, 6 perennial caespitose grasses, and 7 perennial rhizomatous grasses in the summer experiment. Grasses were treated with sulfosulfuron at the rate of $70 \mathrm{~g}$ ai ha ${ }^{-1}$ or not treated (control). Asterisks denote significant differences between the control and sulfosulfuron treatment means within a species and growth variable $(\mathrm{P}<0.05)$.

\begin{tabular}{|c|c|c|c|c|c|}
\hline $\begin{array}{l}\text { Grass } \\
\text { life form }\end{array}$ & Species common name & Treatment & Photosynthesis & Tiller number & Shoot dry mass \\
\hline \multirow[t]{2}{*}{ Annual } & downy brome & $\begin{array}{l}\text { control } \\
\text { sulfosulfuron }\end{array}$ & $\begin{array}{c}--\left(\mu \mathrm{mol} \mathrm{CO}_{2} \mathrm{~m}^{-2} \mathrm{sec}^{-1}\right) \cdots \\
* 16.0(1.8) \\
-1.0(5.4)\end{array}$ & $\begin{array}{c}* 93.0(13.0) \\
11.3(1.3)\end{array}$ & $\begin{array}{c}* 32.2(1.6) \\
18.9(1.7)\end{array}$ \\
\hline & medusahead & $\begin{array}{l}\text { control } \\
\text { sulfosulfuron }\end{array}$ & $\begin{array}{r}15.0(4.3) \\
7.2(3.8)\end{array}$ & $\begin{array}{l}112.8(13.0) \\
101.7(13.3)\end{array}$ & $\begin{array}{l}19.2(1.5) \\
20.9(0.6)\end{array}$ \\
\hline \multirow[t]{6}{*}{ Caespitose } & bluebunch wheatgrass & $\begin{array}{l}\text { control } \\
\text { sulfosulfuron }\end{array}$ & $\begin{array}{r}10.2(2.6) \\
9.8(1.7)\end{array}$ & $\begin{array}{l}19.3(6.4) \\
11.0(6.5)\end{array}$ & $\begin{array}{l}23.9(4.7) \\
24.6(1.7)\end{array}$ \\
\hline & Snake River wheatgrass & $\begin{array}{l}\text { control } \\
\text { sulfosulfuron }\end{array}$ & $\begin{array}{r}14.0(2.2) \\
8.1(3.5)\end{array}$ & $\begin{array}{l}5.3(2.4) \\
7.7(6.2)\end{array}$ & $\begin{array}{l}23.6(2.6) \\
20.5(0.7)\end{array}$ \\
\hline & crested wheatgrass & $\begin{array}{l}\text { control } \\
\text { sulfosulfuron }\end{array}$ & $\begin{array}{l}12.1(1.2) \\
9.47(2.9)\end{array}$ & $\begin{array}{l}36.8(6.6) \\
33.3(4.4)\end{array}$ & $\begin{array}{l}27.1(1.5) \\
27.0(3.8)\end{array}$ \\
\hline & big squirreltail & $\begin{array}{l}\text { control } \\
\text { sulfosulfuron }\end{array}$ & $\begin{array}{l}11.9(2.7) \\
13.4(5.3)\end{array}$ & $\begin{array}{l}11.5(1.9) \\
16.7(8.4)\end{array}$ & $\begin{array}{l}23.1(1.9) \\
20.2(1.7)\end{array}$ \\
\hline & basin wildrye & $\begin{array}{l}\text { control } \\
\text { sulfosulfuron }\end{array}$ & $\begin{array}{l}16.4(0.6) \\
12.6(0.8)\end{array}$ & $\begin{array}{r}* 7.3(2.0) \\
1.3(1.9)\end{array}$ & $\begin{array}{r}* 18.7(1.1) \\
12.9(0.2)\end{array}$ \\
\hline & Russian wildrye & $\begin{array}{l}\text { control } \\
\text { sulfosulfuron }\end{array}$ & $\begin{array}{r}* 18.1(1.6) \\
9.9(2.0)\end{array}$ & $\begin{array}{l}29.8(8.7) \\
19.7(7.1)\end{array}$ & $\begin{array}{l}24.0(0.4) \\
21.8(0.8)\end{array}$ \\
\hline \multirow[t]{7}{*}{ Rhizomatous } & western wheatgrass & $\begin{array}{l}\text { control } \\
\text { sulfosulfuron }\end{array}$ & $\begin{array}{l}20.2(2.3) \\
11.7(7.2)\end{array}$ & $\begin{array}{r}* 100.0(4.1) \\
31.3(5.5)\end{array}$ & $\begin{array}{r}* 25.3(1.0) \\
19.9(1.1)\end{array}$ \\
\hline & thickspike wheatgrass & $\begin{array}{l}\text { control } \\
\text { sulfosulfuron }\end{array}$ & $\begin{array}{l}17.2(2.8) \\
11.2(1.5)\end{array}$ & $\begin{array}{l}36.8(7.8) \\
11.0(5.1)\end{array}$ & $\begin{array}{l}23.9(1.3) \\
22.2(0.3)\end{array}$ \\
\hline & intermediate wheatgrass & $\begin{array}{l}\text { control } \\
\text { sulfosulfuron }\end{array}$ & $\begin{array}{r}* 12.9(0.6) \\
8.3(0.5)\end{array}$ & $\begin{array}{l}5.8(3.8) \\
1.3(0.9)\end{array}$ & $\begin{array}{l}27.2(0.3) \\
28.7(0.2)\end{array}$ \\
\hline & NewHy wheatgrass & $\begin{array}{l}\text { control } \\
\text { sulfosulfuron }\end{array}$ & $\begin{array}{r}14.4(3.7) \\
4.2(1.8)\end{array}$ & $\begin{array}{r}* 26.0(5.5) \\
4.7(4.7)\end{array}$ & $\begin{array}{r}* 30.9(1.0) \\
22.4(0.8)\end{array}$ \\
\hline & beardless wildrye & $\begin{array}{l}\text { control } \\
\text { sulfosulfuron }\end{array}$ & $\begin{array}{r}* 14.2(1.5) \\
3.7(2.4)\end{array}$ & $\begin{array}{r}* 62.3(5.0) \\
24.0(5.1)\end{array}$ & $\begin{array}{r}* 22.2(1.5) \\
14.9(1.3)\end{array}$ \\
\hline & quackgrass & $\begin{array}{l}\text { control } \\
\text { sulfosulfuron }\end{array}$ & $\begin{array}{r}* 10.8(2.1) \\
4.5(1.4)\end{array}$ & $\begin{array}{r}* 37.8(8.0) \\
0.5(0.5)\end{array}$ & $\begin{array}{r}* 16.1(0.6) \\
13.4(0.5)\end{array}$ \\
\hline & smooth brome & $\begin{array}{l}\text { control } \\
\text { sulfosulfuron }\end{array}$ & $\begin{array}{r}* 12.5(0.4) \\
9.0(0.6)\end{array}$ & $\begin{array}{r}* 46.8(0.6) \\
5.3(3.5)\end{array}$ & $\begin{array}{r}* 27.2(0.6) \\
19.6(1.8)\end{array}$ \\
\hline
\end{tabular}

affect photosynthesis. In general terms, a leaf is provided with excess light and measurements of fluorescence are taken to determine the capacity of plants to use the excess light, which depends on the integrity of the photosynthetic machinery.

The effects of sulfosulfuron on photosynthesis, Fv'/Fm', and shoot growth were analyzed with analysis of variance using PROC GLM (SAS Institute, Cary, N.C.). The spring experiment was analyzed as a repeated measures experiment, and the summer experiment as a completely randomized experiment. Individual grass species were analyzed separately and treatment means were compared with Tukey's (HSD) test when significant treatment effects were observed. Treatment effects were considered significant only when $\mathrm{P}<0.05$.

\section{Results}

\section{Photosynthetic Responses}

Photosynthetic activity of downy brome plants in both experiments was severely reduced (76 to $100 \%$ ) by sulfosulfuron, while photosynthesis of medusahead was reduced only in the spring experiment
(Table 2; Fig. 2). Russian wildrye (spring and summer) and basin wildrye and big squirreltail (spring) were the only caespitose grasses to express reductions in photosynthesis when exposed to sulfosulfuron. In contrast, all rhizomatous grasses except thickspike wheatgrass, showed a significant reduction in photosynthesis following exposure to sulfosulfuron in at least one of the experiments. Photosynthesis of the 3 rhizomatous grasses beardless wildrye, quackgrass, and smooth brome was significantly reduced by sulfosulfuron in both spring and summer. 


\section{Chlorophyll fluorescence}

Values of Fv'/Fm', showed that sulfosulfuron directly impacted photochemical efficiency and the ability of plants dissipate excess light energy through photochemical processes (Fig. 3). Sulfosulfuron appeared to impact grasses in 3 distinctly different patterns. One pattern was characterized by a temporary significant decrease in Fv'/Fm' followed by a recovery in photosystem II efficiency at some point during the spring experiment. Both of the invasive annual grasses, the caespitose grasses Snake River wheatgrass and basin wildrye, and the rhizomatous grasses western wheatgrass, beardless wildrye, and smooth brome responded according to this pattern. Another pattern was demonstrated by sulfosulfuron significantly decreasing Fv'/Fm' at a point during the experiment followed by the failure of the species to recover photosynthetic efficiency. This second pattern was observed for the caespitose grasses big squirreltail and Russian wildrye, and the rhizomatous grasses thickspike wheatgrass. A third pattern of response to sulfosulfuron is characterized by pronounced reductions in Fv'/Fm' at some date later than Day 10. Delayed photosynthetic efficiency responses to sulfosulfuron only were observed in the rhizomatous grasses NewHy wheatgrass, quackgrass, and smooth brome.

\section{Shoot growth responses}

Shoot dry mass and tiller number of downy brome plants were significantly lower in the sulfosulfuron treatment compared to the untreated control for both experiments (Tables 2 and 3). Smaller medusahead plants in the spring experiment showed significant reductions in tiller number and shoot dry mass when treated with sulfosulfuron relative to the control. In contrast, larger medusahead plants in the summer experiment failed to show a significant response to sulfosulfuron. Similarly, while basin wildrye was the only caespitose grass that showed a significant reduction in tiller number ( 86 $\%)$ or shoot dry mass when treated with sulfosulfuron in the summer experiment, smaller plants of basin wildrye as well as big squirreltail and Russian wildrye had significantly lower tiller number and shoot dry mass when treated with sulfosulfuron compared to the control in the spring experiment. Unlike the caespitose grasses, the majority of rhizomatous grasses ( 5 of 7) had significantly reduced tiller number and shoot dry mass in the sulfosulfuron treatment relative to the control in both

Table 3. Mean ( $\pm 1 \mathrm{SE} ; n=4$ ) number of tillers and shoot dry mass produced by 2 invasive annua grasses, 6 perennial caespitose grasses, and 7 perennial rhizomatous grasses in the spring experiment. Grasses were treated with sulfosulfuron at the rate of $70 \mathrm{~g}$ ai ha $\mathbf{~ h a ~}^{-1}$ or treated (control). Asterisks denote significant differences between the control and sulfosulfuron treatment means within a species and growth variable $(P<0.05)$.

\begin{tabular}{|c|c|c|c|c|}
\hline $\begin{array}{l}\text { Grass } \\
\text { life form }\end{array}$ & Species & Treatment & Tiller number & Shoot Dry mass \\
\hline & & & & ( \\
\hline \multirow[t]{4}{*}{ Annual } & downy brome & control & *193.0 (24.7) & *13.1 (0.9) \\
\hline & & sulfosulfuron & $24.0(5.2)$ & $2.0(0.4)$ \\
\hline & medusahead & control & $* 164.5(15.9)$ & $* 5.9(0.5)$ \\
\hline & & sulfosulfuron & $101.3(13.2)$ & $3.8(0.3)$ \\
\hline \multirow[t]{8}{*}{ Caespitose } & bluebunch wheatgrass & control & $31.5(10.5)$ & $2.7(0.9)$ \\
\hline & (6) & sulfosulfuron & $15.8(8.1)$ & $1.2(0.4)$ \\
\hline & Snake River wheatgrass & control & $45.8(9.6)$ & $4.3(1.3)$ \\
\hline & & sulfosulfuron & $51.5(9.8)$ & $3.0(0.5)$ \\
\hline & crested wheatgrass & control & $-91.8(6.2)$ & $9.1(1.1)$ \\
\hline & & sulfosulfuron & $74.5(10.6)$ & $6.8(1.4)$ \\
\hline & big squirreltail & control & $* 31.8(2.1)$ & $* 2.2(0.2)$ \\
\hline & & sulfosulfuron & $18.5(2.9)$ & $0.9(0.1)$ \\
\hline \multirow[t]{4}{*}{. } & basin wildrye & control & $* 14.8(1.3)$ & $* 7.4(1.7)$ \\
\hline & & sulfosulfuron & $9.3(1.7)$ & $3.1(0.6)$ \\
\hline & Russian wildrye & control & $* 49.3(2.8)$ & $* 4.6(0.3)$ \\
\hline & & sulfosulfuron & $13.5(0.5)$ & $0.8(0.1)$ \\
\hline \multirow[t]{14}{*}{ Rhizomatous } & western wheatgrass & control & *29.5 (2.9) & $* 6.7(0.8)$ \\
\hline & & sulfosulfuron & $12.0(1.9)$ & $1.7(0.1)$ \\
\hline & thickspike wheatgrass & control & $29.5(8.3)$ & $2.8(0.8)$ \\
\hline & & sulfosulfuron & $21.3(2.3)$ & $1.6(0.1)$ \\
\hline & intermediate wheatgrass & control & $15.8(3.6)$ & $2.2(0.3)$ \\
\hline & & sulfosulfuron & $12.5(1.3)$ & $1.6(0.1)$ \\
\hline & Newhy wheatgrass & control & $* 57.5(6.5)$ & $* 5.9(0.2)$ \\
\hline & & sulfosulfuron & $14.3(1.5)$ & $1.3(0.1)$ \\
\hline & beardless wildrye & control & $* 42.0(3.1)$ & $* 9.0(0.7)$ \\
\hline & & sulfosulfuron & $15.5(2.7)$ & $2.6(0.5)$ \\
\hline & quackgrass & control & $* 39.3(1.0)$ & $* 3.0(0.2)$ \\
\hline & & sulfosulfuron & $12.3(1.9)$ & $1.1(0.2)$ \\
\hline & smooth brome & control & $* 35.0(4.9)$ & $* 5.2(0.8)$ \\
\hline & & sulfosulfuron & $7.5(0.3)$ & $1.1(0.1)$ \\
\hline
\end{tabular}

spring and summer experiments. With the exception of intermediate wheatgrass in the summer experiment, the 2 rhizomatous grasses that did not experience a significant growth response to sulfosulfuron, (i.e., thickspike and intermediate wheatgrass), also did not show photosynthetic responses to sulfosulfuron relative to the untreated control.

\section{Discussion}

Results of these experiments indicate that sulfosulfuron mediated reductions in photosynthesis and shoot growth in these 15 grasses can be classified into 3 main categories: generally unresponsive, generally responsive, and responsiveness dependent on plant age and/or stage of develop. ment (Table 4). Bluebunch; Snake River, crested, thickspike, and intermediate wheatgrasses clearly fall into the generally unresponsive category. Grasses that wert generally responsive include downy brome, basin and beardless wildrye, western and NewHy wheatgrass, quackgrass and smooth brome because they al demonstrated numerous reductions in physiological or growth parameters in response to sulfosulfuron. Medusahead, 
big squirreltail, and Russian wildrye were also susceptible to sulfosulfuron, but greater reductions in shoot growth and photosynthetic activity in small than large plants suggest that responsiveness in these grasses is partially dependant on size or stage of development. Based on these results we reject the hypothesis that sulfosulfuron induced reduction in photosynthetic activity and shoot growth is more pronounced in small relative to large plants, because only 3 of the 15 species were more responsive in the spring than the summer experiment.

The absence of photosynthetic and shoot growth reductions in the generally unresponsive group of grasses likely reflect the ability of these species to metabolize sulfosulfuron. Olson et al. (2000) found that wheat (Triticum aestivum L.) rapidly metabolizes sulfosulfuron into a non-lethal metabolite and avoids injury, whereas downy brome, jointed goatgrass (Aegilops cylindrica Host.), and wild oat (Avena fatua L.) were susceptible to injury because they have lower abilities to metabolize sulfosulfuron. Intrinsic growth rate and cuticle surface texture are 2 additional factors that may interact to determine herbicide absorption and partly explain our observed differences between the invasive annual grasses in response to sulfosulfuron. High growth rates in downy brome and medusahead, even at low temperature (Aguirre and Johnson 1991), suggest they may have higher foliar herbicide absorption and subsequent physiological impacts. However, these invasive annual grasses conspicuously differ in leaf surface texture. Medusahead leaves develop a tough cuticle high in silica as they mature (Bovey et al. 1961), whereas downy brome maintains soft, frail leaves. Consequently, older medusahead plants may have been

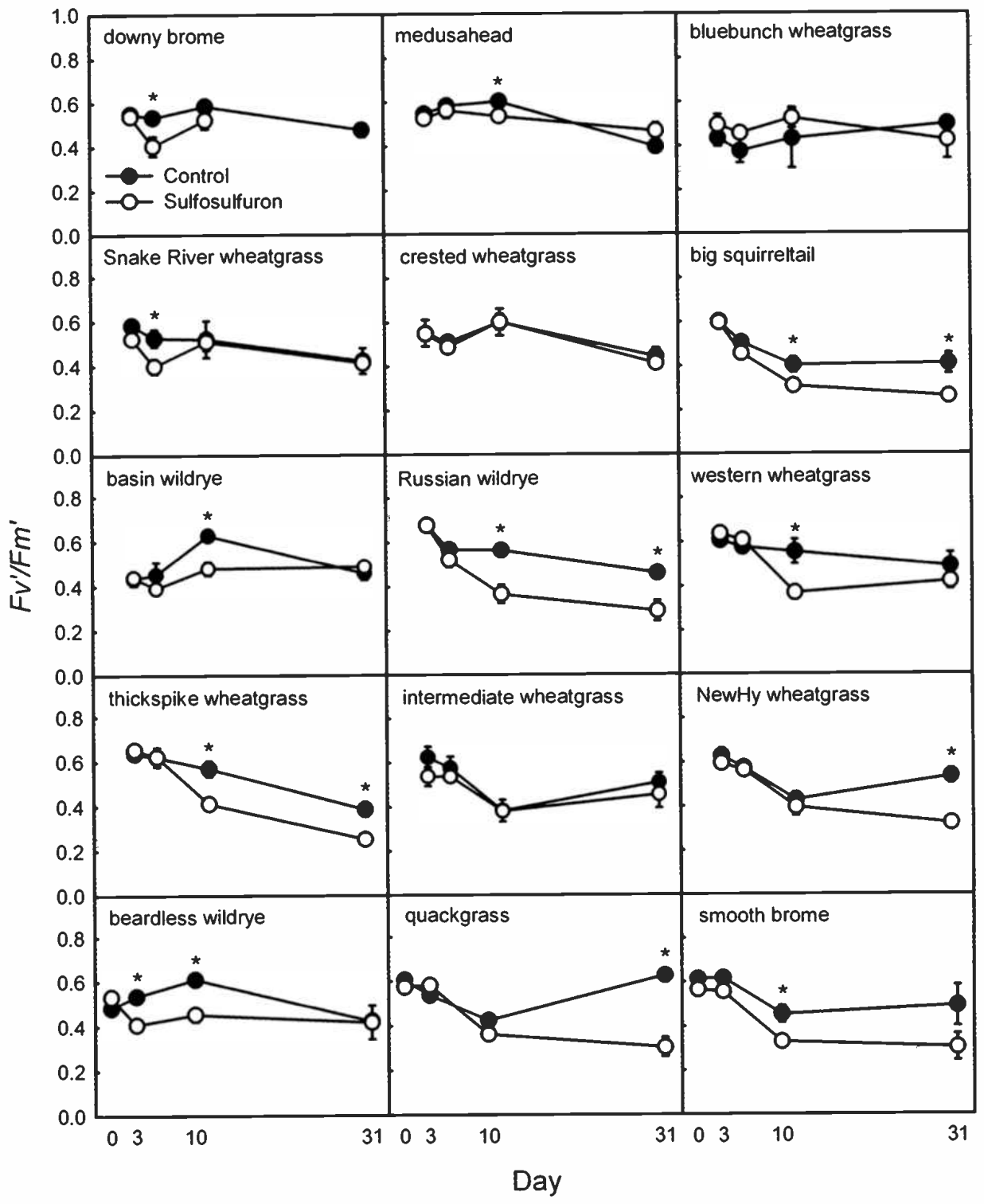

Fig. 3. Mean ( $\pm 1 \mathrm{SE}, \mathrm{n}=4$ ) $\mathrm{Fv} / \mathrm{Fm}$ ' (potential quantum yield of photosystem II) for 15 grasses exposed to sulfosulfuron at the rate of $70 \mathrm{~g}^{\text {ai }} \mathrm{ha}^{-1}$ or not treated (control). Measurements were made prior to herbicide treatment (Day 0) and on Days 3, 10, and 31. Asterisks indicate significant differences between the sulfosulfuron treatment and control within a specific day.

Table 4. Characterization of responsiveness to sulfosulfuron for the 15 grasses evaluated. Significant (+) and non-significant (0) treatment responses relative to the control are shown for number of tillers, shoot dry mass, leaf photosynthesis and Fv'/Fm' for the spring (left column) and summer experiment (right column).

\begin{tabular}{|c|c|c|c|c|c|c|c|c|}
\hline \multirow{2}{*}{$\frac{\text { Species }}{\text { downy brome }}$} & \multicolumn{2}{|c|}{ Tiller number } & \multicolumn{2}{|c|}{ Shoot dry mass } & \multicolumn{2}{|c|}{ Photosynthesis } & \multirow{2}{*}{$\frac{\text { Fv'/Fm' }}{+}$} & \multirow{2}{*}{$\begin{array}{c}\text { Category } \\
\text { responsive }\end{array}$} \\
\hline & + & + & + & + & + & + & & \\
\hline medusahead & + & 0 & + & 0 & + & 0 & + & size-dependent \\
\hline bluebunch wheatgrass & 0 & 0 & 0 & 0 & 0 & 0 & 0 & unresponsive \\
\hline Snake River wheatgrass & 0 & 0 & 0 & 0 & 0 & 0 & + & unresponsive \\
\hline crested wheatgrass & 0 & 0 & 0 & 0 & 0 & 0 & 0 & unresponsive \\
\hline big squirreltail & + & 0 & + & 0 & + & 0 & + & size-dependent \\
\hline basin wildrye & + & + & + & + & + & 0 & + & responsive \\
\hline Russian wildrye & + & 0 & + & 0 & + & + & + & size-dependent \\
\hline western wheatgrass & + & + & + & + & + & 0 & + & responsive \\
\hline thickspike wheatgrass & 0 & 0 & 0 & 0 & 0 & 0 & + & unresponsive \\
\hline intermediate wheatgrass & 0 & 0 & 0 & 0 & 0 & + & 0 & unresponsive \\
\hline NewHy wheatgrass & + & + & + & + & + & 0 & + & responsive \\
\hline beardless wildrye & + & + & + & + & + & + & + & responsive \\
\hline quackgrass & + & + & + & + & + & + & + & responsive \\
\hline smooth brome & + & + & + & + & + & + & + & responsive \\
\hline
\end{tabular}


unresponsive to sulfosulfuron because of structural limitations on absorption, even though it has a relatively high growth rate. The same rational does not hold as well for the perennial grasses. Namely, basin wildrye and western wheatgrass both have prominent rough leaves, but both were distinctly damaged by sulfosulfuron.

Evolutionary relationships between the perennial grasses may provide a partial explanation for greater sulfosulfuron responsiveness in the rhizomatous compared to the caespitose grasses we evaluated (Dewey 1983, Barkworth et al. 1983). For example, thickspike wheatgrass and beardless wildrye are both rhizomatous grasses; however, the former was generally unresponsive and the latter was responsive to sulfosulfuron. It is interesting to note that a descendent of these rhizomatous grasses is western wheatgrass, a sulfosulfuron sensitive rhizomatous grass. Susceptibility to sulfosulfuron in western wheatgrass likely originated from its responsive ancestor beardless wildrye. Similarly, the unresponsive caespitose grass bluebunch wheatgrass and the highly responsive rhizomatous grass quackgrass are the parents of the moderately rhizomatous grass NewHy wheatgrass. It is likely that NewHy wheatgrass responsiveness to sulfosulfuron is associated with morphological or physiological traits passed on from quackgrass.

Photosynthesis and Fv'/Fm' were effective quantitative indicators of herbicide impacts in these experiments. Experiments indicated a strong association between herbicide effects on photosynthetic processes and subsequent shoot growth. Plant size and/or stage of development did not appear to be a strong factor determining responsiveness for the majority of the species we evaluated. However, our observation that small medusahead plants were consistently more susceptible to sulfosulfuron than large plants, suggests that control of this invasive weed may be improved in the field by targeting plants when they are small in late autumn or early spring (Horton 1991). In these greenhouse studies, caespitose grasses were generally less injured than rhizomatous grasses by sulfosulfuron treatments; however, the mechanisms responsible for these observations are not totally clear. Leaf texture and growth rate may be additional factors associated with foliar activity of sulfosulfuron for some grasses.

\section{Literature Cited}

Aguirre, L. and D.A. Johnson. 1991. Influence of temperature and cheatgrass competition on seedling development of two bunchgrasses. J. Range Manage. 44:347-354.

Anonymous. 1999. Outrider TM Product Label. 71014X1-2/CG. Monsanto Company. St. Louis, Mo.

Arredondo, J.T., T.A. Jones, and D.A. Johnson. 1998. Seedling growth of Intermountain perennial and weedy annual grasses. J. Range Manage. 51:584-589.

Barkworth, M.E., D.R. Dewey, and R.J. Atkins. 1983. New generic concepts in the Triticeae of the Intermountain Region: Key and comments. Great Basin Natur. 43:561-572.

Blackshaw, R.E. and W.M. Hammon. 1998. Control of downy brome (Bromus tectorum) in winter wheat (Triticum aestivum) with MON 37500. Weed Technol. 12:421-425.

Bilger, W., U. Schreiber, and M. Bock. 1995. Determination of the quantum efficiency of photosystem II and non-photochemical quenching of chlorophyll fluorescence in the field. Oecologia 102:425-432.

Bovey, R.W., D. Le Tourneau, and L.C. Erikson. 1961. The chemical composition of medusahead and cheatgrass. Weeds 9:307-311.

Chaleff, R.S. and C.J. Maurais. 1984. Acetolactate synthase is the site of action of two sulfonylurea herbicides in higher plants. Sci. 224:1443-1445.

D'Antonio, C. M. and P.M. Vitousek 1992. Biological invasions by exotic grasses, the grass/fire cycle, and global change. Ann. Rev. Ecol. and Syst. 23:63-87.

Dewey, D.R. 1983. New nomenclatural combinations in the North American perennial Triticeae (Gramineae). Brittonia 35: 30-33.

Geier, P.W. and P.W. Stahlman. 1996. Doseresponses of weeds and winter wheat (Triticum aestivum) to MON 37500. Weed Technol. 10:870-875.

Geier, P.W., P.W. Stahlman, R.E. Northam, S.D. Miller, and N.R. Hageman. 1998. MON 37500 rate and timing affects downy brome (Bromus tectorum) control in winter wheat (Triticum aestivum). Weed Sci. 46:366-373.

Genty, B., J-M. Briantais, and N.R. Baker. 1989. The relationship between the quantum yield of photosynthetic electron transport and quenching of chlorophyll fluorescence. Biochim. Biophys. Acta. 990:87-92.

Hageman, N.R., S.E. Blank, G.L. Cramer, P.J. Isakson, D.K. Ryerson, and S.K. Parrish. 1996. MON 37500: a new selective herbicide to control annual and perennial weeds in wheat. Proc. West. Soc. Weed Sci. 49:78-82.
Hinz, J.R.R., M.D.K. Owen, and M. Barrett 1997. Nicosulfuron, primisulfuron, and bentazon hydroxylation by corn (Zea mays), woolly cupgrass (Eriochloa villosa) and shat tercane (Sorghum bicolor) cytochrome $\mathrm{P}$. 450: Weed Sci. 45 474-480.

Horton, W. H. 1991. Medusahead: impor tance, distribution, and control, p. 394-398 In: L. F. James, J. O. Evans, M. H. Ralphs and R. D. Childs (eds.) Noxious range weeds. Westview Press, Boulder, Colo.

Kelley, J.P. and T.F. Peeper. 2003. MON 37500 application timing affects cheal (Bromus secalinus) control in winter wheat Weed Sci. 51:231-236.

Olson, B.L.S., K. Al-Khatib, P. Stahlman and P.J. Isakson. 2000. Efficacy and metabolism of MON 37500 in Triticum aestivum and weedy grass species as affected by tem. perature and soil moisture. Weed Sci 48:541-548.

van Kooten, O. and J.F.H. Snel. 1990. The use of chlorophyll fluorescence nomenclature in plant stress physiology. Photosyn. Res. 25:127-150. 